\title{
Cotidiano
}

\section{MUDAR DE LADO}

Hoje em dia fala-se em mudança, quer-se um mundo melhor, sem fome, sem violência e com líderes honestos. Não se preocupam, nem imaginam que o problema somos nós mesmos, antes de tudo. Que cada um de nós é que pode consertar o mundo. Tem-se de entender que se é responsável pelo mal ou bem do que ocorre a nossa volta.

Li alguns livros sobre a Neurolinguística. Quase todos bons, mas sempre deixando de falar mais alguma coisa. Essa coisa que ninguém diz e é importante e quero, agora, que todos saibam. Temos dois hemisférios cerebrais, esquerdo e direito. Usamos mais um do que outro. E o pior, usa-se, em geral, só o lado equivocado com predominância. Parece ser prático. Mas, como diz Jesus, a porta larga é a da perdição.

Pode-se mudar de lado; passar para o lado que equilibre. Não é fácil, mas é possível. Só quando todos se conscientizarem de mudar é que vamos viver e ver um mundo com tudo de bom que tanto sonhamos. Esta solução compete ao livre-arbítrio de cada pessoa, em particular, que deve evoluir por esforço próprio, sendo-lhe franquado o plantio de uma inevitável colheita.

Temos dentro de nós dois hemisférios cerebrais, esquerdo e direito, a se entrecruzarem nas ramificações para formar o restante dos órgãos, a coordenarem lados externos contrários, enquanto que se comunicam por faixa estreita denominada corpo caloso o que corresponde a $25 \%$ da área fronteiriça, tal ponte de ligação. Estudos de funcionalidade avaliam que existe uma proporção de 1 para 3, de um lado sobre o outro, as mesmas equivalências de terra e água na face do globo terrestre.

Perante a dúvida de qual hemisfério se usa com predominância, busquemos classificar nossos pensamentos comuns. Quando positivos, otimistas, construtivos, para o bem, para o sucesso, sinais evidentes da utilização do hemisfério direito (coração). Caso inverso - do esquerdo (razão). Devemos mudar de lado, passar ao outro hemisfério cerebral. Essa mudança hemisférica é possível. 
Sobre essas coisas até pouco tempo eu também quase nada sabia. Quando voltei a morar no Crato, Ceará (1987), revi um amigo da família que nos visitava com freqüência (Emerson Monteiro). Ele sempre falava coisas boas, positivas. E divulgava tese bem interessante. Descobrira dentro de si os pólos negativo e o positivo e os localizara no corpo físico. Lera e interpertrara o que dizia Jesus: Meu caminho é o do coração.

Sabemos, pelos estudos, ser nosso cérebro dividido em duas partes. E que a esquerda comanda o lado direito do corpo. E a direita, o lado esquerdo do corpo. Usamos com predominância mais um lado do que o outro. E isto se apresenta em nossa própria presença estabelecida sob a mesma concepção dualista.

Depois de certo tempo de convivência, Emerson resolveu me contar como ele passara a ser cobaia dessa tese, nas palavras que agora quero aqui transcrever na íntegra:

Tudo começou no ano de 1967, em Brejo Santo, Ceará, quando li isso pela primeira vez, num livro sobre Macrobiótica (dieta oriental à base de cereal integral). Esse sistema alimentar se estrutura sobre o Princípio Único do Universo (yin/yang), a Lei da Bipolaridade: Tudo tem o seu contrário para poder existir.

Usei essa alimentação por mais de dez anos, comprovando a validade da tese no equilibro do potássio e do sódio que existem nos alimentos, o doce e o salgado, contrários que sobrevêm na vida material. Com o passar do tempo, cheguei a outras questões que não eram só de alimentação; achei de procurar na minha vida onde estariam essas polaridades, nos aspectos internos do ser pessoal.

No ano de 1977, já tendo vivido em Salvador, Bahia, e voltado para o Crato, tentava localizar tais polaridades no funcionamento na Mente. Passara uma temporada fotografando pessoas e estudando em laboratório essas fotografias. Vira que as pessoas têm dois lados no rosto, e tentava ver onde estariam as tais polaridades, negativa e positiva, dentro das funções externas da fisionomia de cada um de nós.

Sabia não ser coisa aleatória, que a natureza não faz nada aleatório. Fui procurando... Procurando... Em novembro daquele ano (1977), no princípio do mês, quando fazia um filme (Terra Ardente) que não cheguei a concluir, morando numa casa no distrito do Lameiro, casinha típica do sertão, de taipa e telha, e sempre colhendo novas informações sobre o tal assunto de estudos, encontrei, no jornal Movimento (número 132), artigo de Marshall Mcluhan (teórico canadense de Comunicação), onde afirmava que a humanidade não estava perdida, que poderia sintonizar seu outro lado e desenvolver a outra polaridade do Ser. Com isto venceria limitações quais a inflação, a recessão, a fome, a guerra, a tudo renovando por meio do trabalho, da solidariedade, da união. Mas que cada um tem de haver 
uma mudança estrutural. Ele demonstrava que a referência equivalia aos hemisférios cerebrais, que seriam os dois pólos dentro do ser humano.

Quando li esse artigo estava vivendo um conflito dos mais dificeis, verdadeira tempestade da alma, periodo de profundos tumultos interiores. Fiquei satisfeito com as novas notícias, que coincidiam de perto com os resultados de minha procura.

Da noite para o dia, numa madrugada de fim de ano, vim a reconhecer o conhecimento adquirido e mudei de lado. Foi quando tive a oportunidade de conversar comigo mesmo. Um lado com o outro, como duas pessoas distintas, sem qualquer dúvida. As funções negativa e positiva em diálogo externo, cada uma delas correspondendo a um dos hemisférios cerebrais.

A partir dessa hora resolvi me estabelecer num dos lados, assumir a posição, tendo consciência perfeita do onde me fixei. Vi onde estava dentro de mim mesmo, em que lado, qual olho correspondia ao hemisfério que utilizava com prioridade, mantendo o outro como seu assessor, compreendendo às proporções de l para 3, confirmadas pela Ciência através de precisos instrumentos (25 para 75\%). Ninguém estará sempre a 50\% de cada lado. Ou $25 / 75 \%$ ou $75 / 25 \%$, dadas as constantes variações de função.

Na hora em que resolvi mudar, que conversei um lado com o outro, vi que estava indo a mais dificuldade por via da exacerbação do conflito, o que não soube, de início, compreender. Levantara uma nova bandeira, a da mudança radical, afirmando: - Por favor, resolvi tomar de conta do meu barco; queira sair do meio, pois a partir deste momento quem vai dominar sou eu (falava dentro de mim qual se conversasse com outra pessoa).

Então, o outro lado reagiu dizendo: - Permita uma nova chance. Estas coisas todas vão passar; de agora em diante vou acertar; deixar de repetir coisas erradas. A vida vai ficar diferente. E o diálogo ainda prosseguiu, com o outro lado voltando à carga: - Não, a sua fase já passou, ficou para trás. Quero chegar no comando e determinar os caminhos de minha vida. Por favor, me deixe por dono dessa orientação.

Ainda que desta maneira, o meu outro lado não aceitou de bom grado sua desestabilização do poder. Permaneceu em oposição velada, que durou até o ano seguinte, fase em que vivi um verdadeiro inferno existencial. Conflitos que se sucediam a cada momento, contradições a serem vencidas. Mas fui superando, mantendo acesa a chama. Notei que deveria abandonar vícios, pensamentos nocivos, más influências, os aliados negativos da velha personalidade. E querer de verdade sair inteiro dessa história.

Em 13 de maio de 1978, à tarde, na Serra do Araripe, vivenciei experiência profunda que me alterou em definitivo o modo de ver o mundo, fazendo-me aceitar as coisas 
Id en line Revista de Psicologia. Ano 2, No. 5, Julho de 2008 - ISSN 1981-1179.

invisíveis como realidade objetiva, consolidando a posição percebida e desenvolvida para realizar uma mudança de vida.

(1) Danielle Gomes Lacerda é Escritora. E-mail: emersomonteiro@gmail.com. 